\title{
Geochemical and biostratigraphic constraints on the genesis of mafic intrusive in the Buxa Dolomite (Neoproterozoic), Panging area of the Arunachal Lesser Himalaya, north east India
}

\author{
*A. K. Singh and V. C. Tewari \\ Wadia Institute of Himalayan Geology, Dehradun - 248001, Uttarakhand, India \\ (*Email: aksingh_wihg@rediffmail.com)
}

\begin{abstract}
Mafic intrusive within Neoproterozoic carbonates of Miri-Buxa Group in the Panging area of the Arunachal Lesser Himalaya, NE India has been reported for the first time. These mafic rocks have affinity to subalkaline-Mg-tholeiites and identified as low-Ti gabbro. Geochemically they are characterized by enrichment in LILE and LREE, depleted in HFSE with minor REE fractionated nature $\left.\left[(\mathrm{La} / \mathrm{Yb})_{\mathrm{N}}=2.70-3.29\right)\right]$ and positive Eu anomalies $\left(\mathrm{Eu} / \mathrm{Eu}^{*}=1.00-1.30\right)$. These rocks have the influence of a within plate signature which were intruded in a continental rift tectonic environment. Petrogenetic modelings of $[\mathrm{Mg}]-[\mathrm{Fe}]$ and REE suggest these mafic rocks probably derived from enriched mantle source similar to komatiitic composition at moderate to higher degree (35\% - 50\%) of partial melt. Based on the present reported microfossils viz. Rivularia haematites and Filamentus cyanobacteria in the chert lenses of the Buxa Dolomite from the Panging area, it is suggested that the gabbroic intrusion might have been taken place during Late Neoproterozoic which is probably close to the Precambrian-Cambrian boundary.
\end{abstract}

Keywords: Gabbro intrusive, Buxa Dolomite, geochemistry, microbiota, Panging area, Arunchal Lesser Himalaya, NE India

Recieved: December 16, 2009

Revision accepted: April 15, 2010

\section{INTRODUCTION}

The Lesser Himalaya has an extensive record of mafic magmatism through Precambrian to Eocene. The mafic magmatisms are preserved in the form of volcanosedimentary sequences, sills/dykes and intrusives (Ahmad and Bhat 1987; Bhat and Ahmad 1990; Srivastava and Sahai 2001; Bhat and Le Fort 1992; Ahmad and Tarney 1994; Gautam et al. 1995; Sengupta et al. 1996; Ahmad et al. 1999; Chaudhari and Gupta 1997). In the last two decades, the mafic magmatic rocks of the eastern Himalaya particularly from Siang Window have been studied (Thakur and Jain 1974; Bhat 1984; Roychowdhury 1984; Bhat and Ahmad 1990; Sengupta et al. 1996; Singh 2006). However, most of the earlier publications are restricted to the mafic volcanics in the core of Siang Window. Till the date no informations on gabbroic intrusive in Siang Window of eastern Himalaya have been reported. Hence, the purpose of this article is to report the petro-geochemical characteristics of gabbroic intrusive to evaluate their petrogenesis, depositional environment and age of the host rock i.e. Buxa Dolomite based on the microfossils.

\section{GEOLOGICAL SETTING}

In the Arunachal Lesser Himalaya the gabbroic intrusion took place along the Siang Valley, the major lithological and tectonic units show a bend in their regional strike from NESW in the west to NW-SE in the east across the Siang gorge is known as the Eastern Syntaxis Bend (Wadia 1931). Western and eastern domains in this easternmost part of Himalaya is separated by the Siang Window directly south of the Eastern Himalayan Syntaxis (Singh 1993; Acharyya et al. 1986; Acharyya 1998; Fig. 1). This syntaxis has been folded across the Siang River into a major antiform and termed as Eastern Syntaxial Bend (Singh 1993; Gururajan and Choudhuri 2003). However, Eastern Himalayan syntaxis from the Chinese side have been also reported (Burg et al. 1998; Ding et al. 2001; Liu et al. 2004). The geological setting of these syntaxes in the Indian and Chinese sides is significantly consistent. Based on field studies, the core of the syntaxis in the Arunachal Lesser Himalaya has been named differently as Siang Antiform (Singh 1993) and Siang Window (Acharyya 1998). All the regional structural features such as the Main Central Thrust, Bame Thrust, and the IndusTsangpo Suture make sharp U-turns round the window. Kumar (1997) also has been defined the window as a closed trace of the Main Boundary Thrust that places Lesser Himalayan Sequence strata. Intensity of metamorphism increases gradually from greenschist facies in the centre to upper amphibolite facies in the periphery (Singh 1993). The window is trucated to the south against the Siwalik sediments accross the North Pasighat Thrust (Acharyya, 2007). At the core of the Siang Window sedimentary rocks 


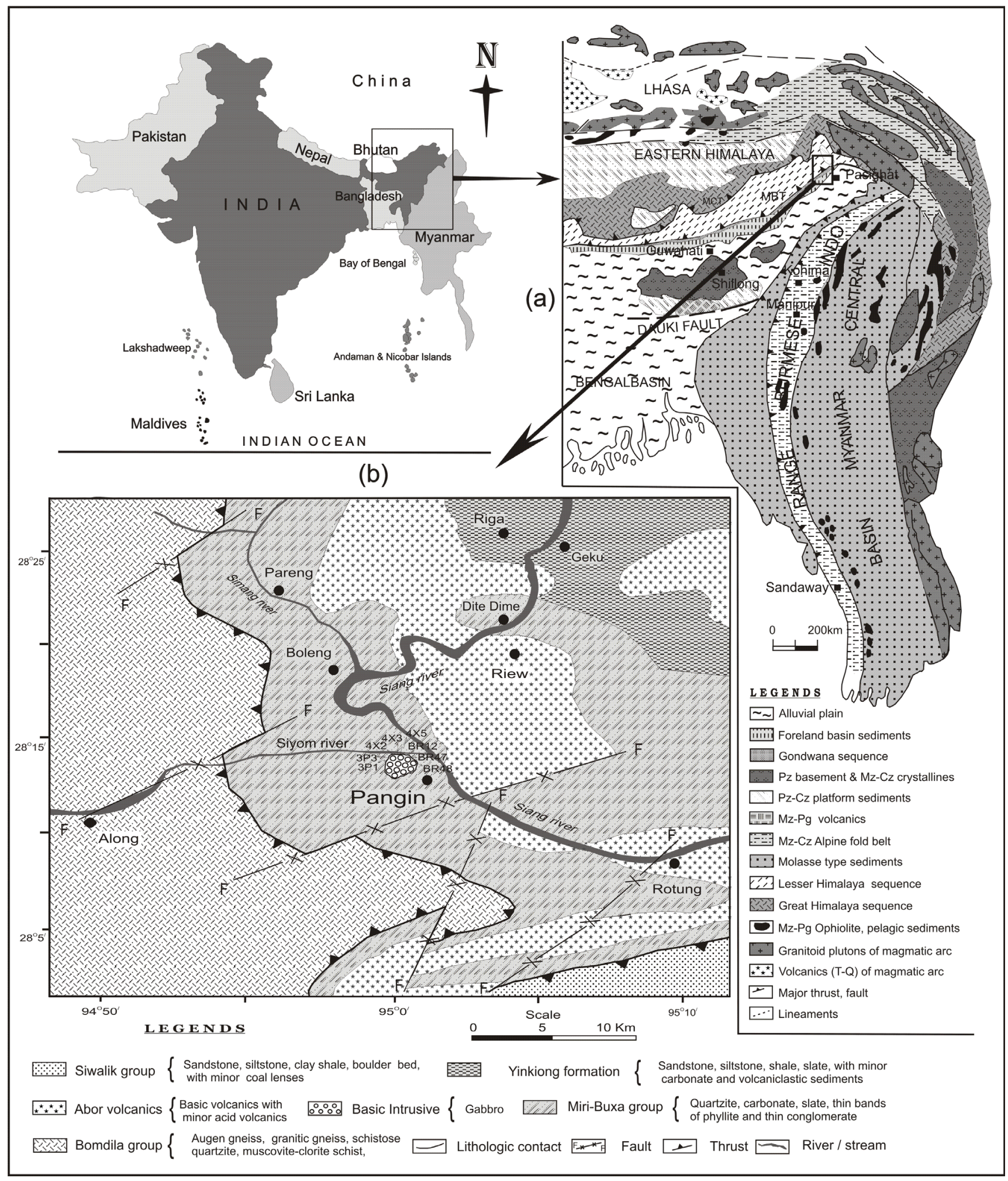

Fig. 1: (a) Generalized geological map of eastern Himalaya and Indo-Myanmar Range ( Acharyya et al. 1986). (b) Geological map of the southern part of Siang Window in Eastern Syntaxial Bend, Arunachal Himalaya (modified after Singh 1993) 
Table 1: Simplified lithostratigraphy of the Buxa-Miri Group Sedimentary succession in the Arunachal Lesser Himalaya, north east India (Tewari 2003)

\begin{tabular}{lcc}
\hline Miri Group & Miri Formation & Lower Cambrian \\
\hline Buxa Group & Dirang Formation & \\
& Dedza Formation & Neoproterozoic \\
& Rupa / Chillipam Formation & \\
& Tenga Formation & \\
& Panging Formation & \\
& (Present study area) & \\
\hline
\end{tabular}

of Miri-Buxa Group interbeded and co-folded with the mafic/ felsic volcanics of Abor Formation and sedimentary rocks of Yinkiong Formation are well exposed (Fig.1b).

The gabbro intrusive is emplaced (Lat. $28^{0} 13.91^{\prime} \mathrm{N}$; Long. 94059.55' E) within the Buxa Carbonates of Miri-Buxa Group (Fig. 1b). The contacts between the gabbros and country rocks are sharp. These intrusives do not show any primary flow alignment or deformation features. The intrusives are devoid of xenoliths of country rocks suggesting their permissive emplacement and lower structural level. The sedimentology, paleobiology and carbon isotopic studies of the Buxa Dolomite and Miri Quartzite have been done in the Kameng, Subansiri and Siang windows (Tewari 1998, 2001, 2002, 2003, 2007, 2009; Shukla et al. 2006). The generalized lithostratigraphy established in the Arunachal Lesser Himalaya (Tewari 2003) is given in Table 1. A Neoproterozoic-Lower Cambrian age has been suggested for the Buxa-Miri Group sediments based on recent discoveris from the Arunachal Lesser Himalaya (Tewari 2001, 2002, 2003, 2007; Shukla et al. 2006). However, the present paper records for the first time a well preserved cyanobacterial remains from the black chert lenses from the Buxa Dolomite exposed between Along and Panging section in the Arunachal Lesser Himalaya. Fig 2 shows the litholog of the Panging Limestone and the position of the black chert lenses yielding cyanobacterial microfossils in the lower part.

\section{PETROGRAPHY}

The gabbros are medium-grained and plagioclase, clinopyroxene, quartz, hornblende are the essential minerals whereas orthopyroxene, chlorite, epidote, sericite, titaniferous magnetite are assessories (Figs. 3a and 3b). These rocks display uniform mineral assemblages and textural relationships. In most of the samples the texture varies from subophitic to ophitic (Fig. 3c). Subhedral to anhedral grains of plagioclase, average $0.3 \mathrm{~mm}$ in diameter, make up about 40-50 modal percent. Plagioclase laths are mostly unzoned, subhedral with corroded margins and faint clouding. Usually plagioclases are tabular and they are sericitized and sassuritized, showing carlsbad twinning. However, fresh and small grains in the medium grained samples exhibit albite twinning. At places, they were partially resorbed and filled by groundmass composed of fine-grained

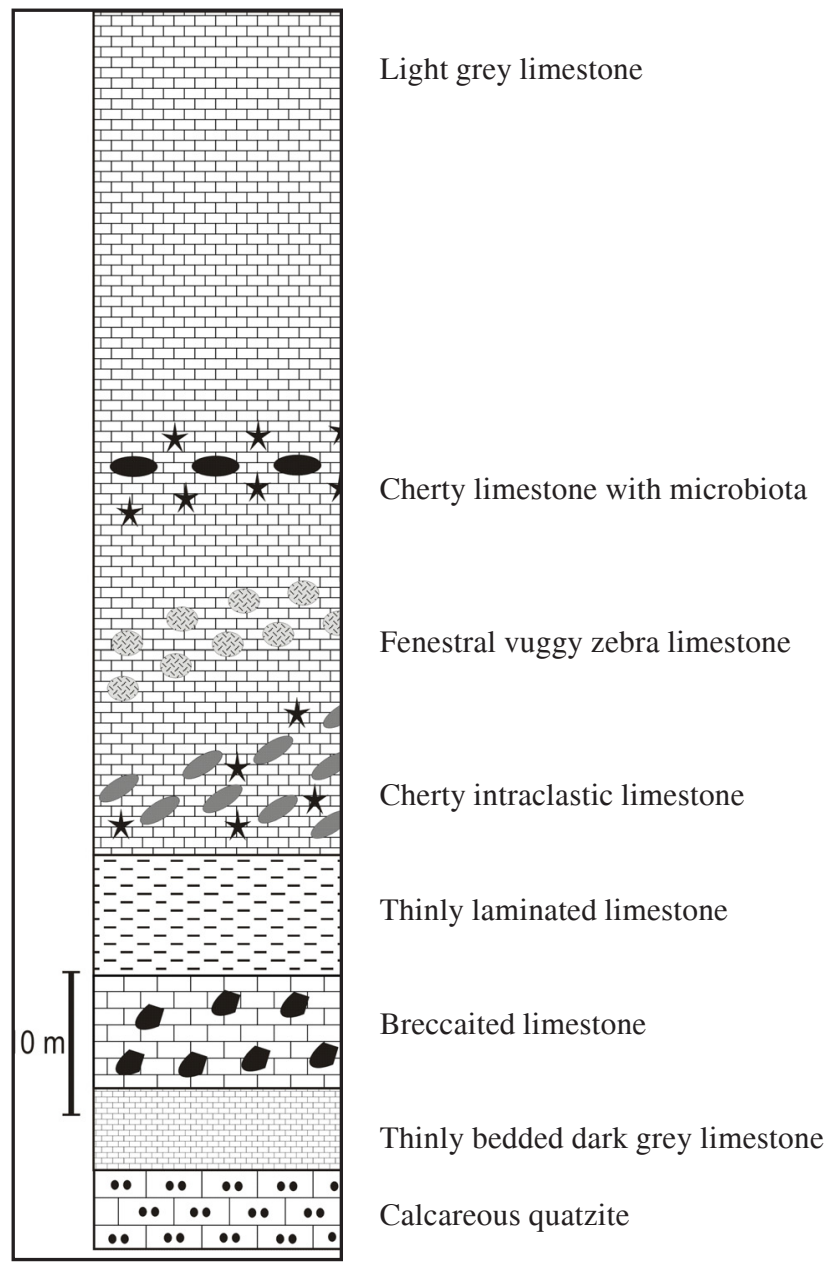

Fig. 2: Litholog of the Buxa Dolomite (Panging Limestone) Along-Panging Road section, Siang Window of the Arunachal Lesser Himalaya

plagioclase, pyroxene, amphibole, quartz and Fe-Ti oxides. Clinopyroxene occurs as euhedral to subhedral phenocryst and either colourless or moderately pleochroic in green to yellowish purple and sometimes show twinning (Fig. 3d). Clinopyroxenes have been altered to chlorite and development of amphibole cleavage is quite common. Hornblende exhibits prismatic shape but the cross sections show hexagonal form. At places, it shows irregular form and along clinopyroxene/plagioclase boundaries small reaction zones of amphiboles are also observed. In most coarsegrained samples the quartz is intimately intergrowth with plagioclase giving rise to granophyric textures (Fig. 3e). In some of the coarse grained samples, granophyric texture is seen at interstitial space between laths of plagioclase feldspars and pyroxene grains. Fine to medium-grained crystals are widely disseminated in the groundmass. Titaniferous magnetite occurs in idiomophic elongated rods across the plagioclase-pyroxene indicating its late origin (Fig. 3f). 

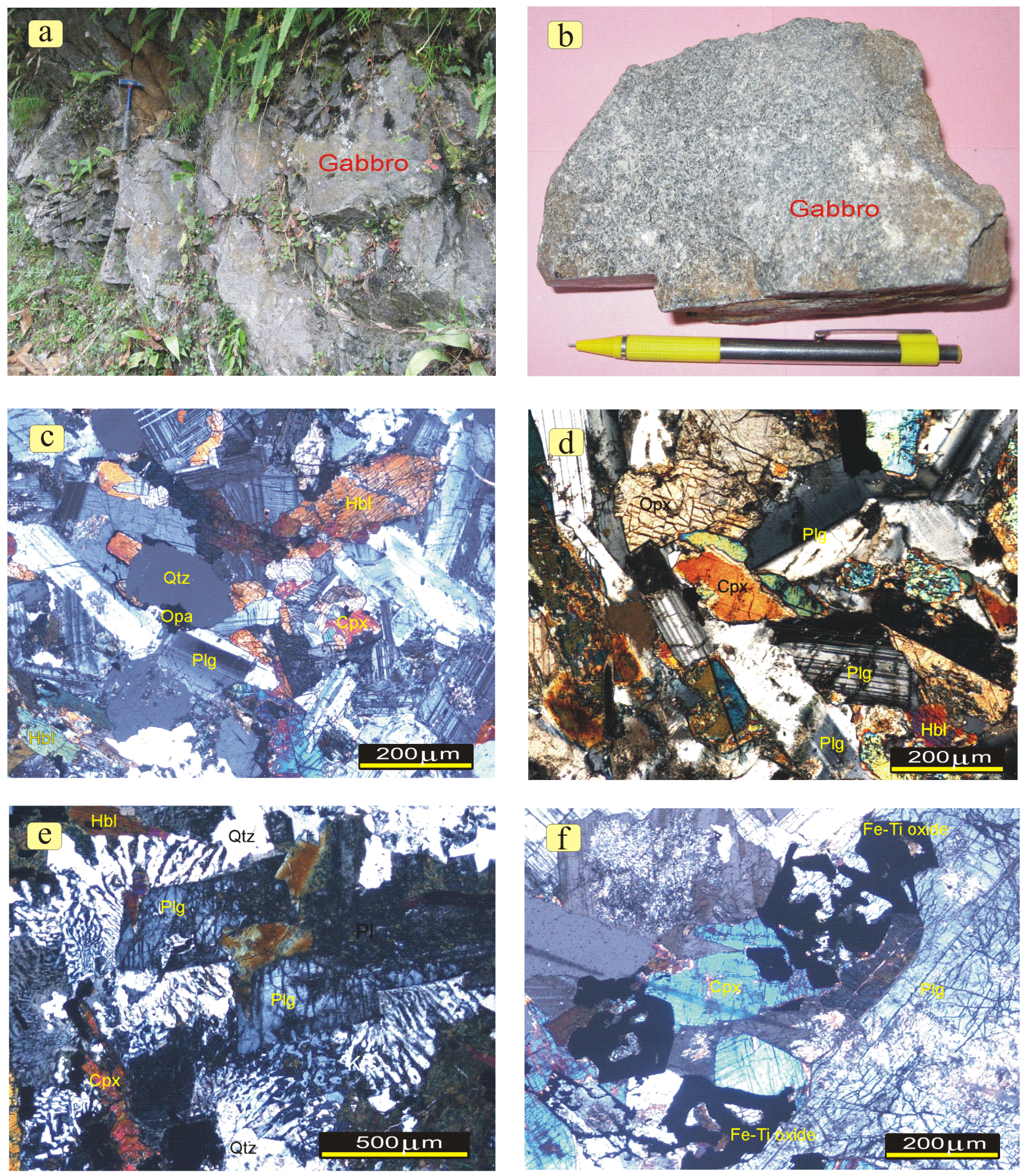

Fig. 3: (a) Outcrop of gabbro intrusive (Lat. 28013.91' N; Long. 94059.55' E). (b) Handspecimen of gabbro. (c) Hypidiophorphic and sub-ophitic texture. (d) Carlsbad twinning in plagioclase. (e) Intergrowth of quartz and plagioclase produced granophyric texture. (f) Skeletal titaniferous magnetite grains. 

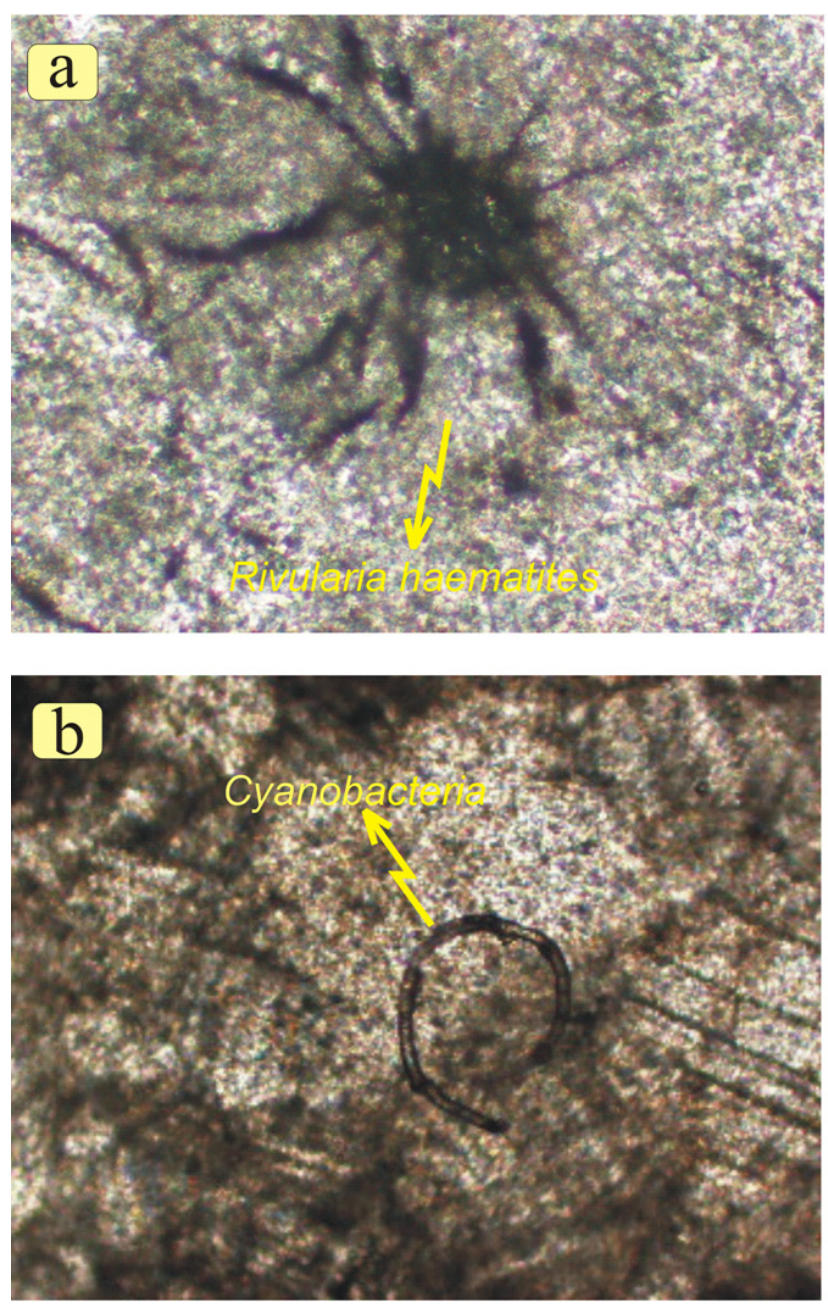

Fig. 4: Photomicrographs of (a) Rivularia haematites (Cyanophyta). (b) Coiled Cyanobacteria from the chert lenses in the Buxa Dolomite, Panging area, Arunachal Lesser Himalya

The petrographic thin sections of the cherts from the Buxa Dolomite reveal the presence of slightly coiled and radiating cyanobacterial filaments (Figs. $4 \mathrm{a}$ and $4 \mathrm{~b}$ ). The petrography of the Buxa Dolomite (Panging Limestone) is characterized by the microfacies micrite, dolosparite, laminated light and dark (organic) carbonate - organic matter.

\section{GEOCHEMISTRY AND PETROGENESIS}

The major and trace elements were determined by XRF whereas rare earth elements (REE) were analysed by ICPMS at Wadia Institute of Himalayan Geology, Dehradun. Analytical precision for major elements is well within \pm 2 to $3 \%$ and for trace elements it is within \pm 5 to $6 \%$. Accuracy of measurement of rare earth elements ranges from 2 to $12 \%$ and precision varies from 1 to $8 \%$. Major elements data and petrogenetic parameters are presented in Table 2 whereas Table 3 shows trace elements including rare earth elements.
These gabbros show low AI values, ranging from 34.97$50.75 \mathrm{wt} . \%$, indicating least affected by secondary alteration processes (Lafleche et al. 1992; Sage et al. 1996). The least alteration effects are also supported by their LOI values $(0.54$ to 1.74). Although, for the magma type classification of these mafic rocks, the trivalent rare earth elements and the high field strength elements (HFSE) such as Th, Hf, $\mathrm{Nb}, \mathrm{Ta}, \mathrm{Zr}$, Ti, Y which are not significantly affected by the alteration and are immobile during low grade metamorphism, are used (Mahoney et al. 2000). The analyzed samples while plotted in the immobile trace elements diagram of $\mathrm{Nb} / \mathrm{Y}$ vs $\mathrm{Zr} / \mathrm{Ti}$ distinguished sub-alkaline mafic rocks (Fig. 5a). Their low $\mathrm{Nb} / \mathrm{Y}$ ratio $(<1$ i.e. $0.39-0.41)$ also indicate subalkaline magmatic rocks (Winchester and Floyd 1977; Pearce and Gale 1977). Based on the $\mathrm{Ti} / \mathrm{Y}$ values (high- $\mathrm{Ti}=\mathrm{Ti} / \mathrm{Y}>500$; low- $\mathrm{Ti}=\mathrm{Ti} / \mathrm{Y}<500)$ these mafic rocks have been classified as low-Ti mafic rocks ( $\mathrm{Ti} / \mathrm{Y}=402.86$ - 477.88) (Peate et al. 1992; Xu et al. 2001). It has been reported that the high-Ti lavas were generated at a lower degree of partial melting, whereas low-Ti lavas could be related to higher degrees of partial melting (Xu et al. 2001). Thus, these intrusives were generated with moderate to higher degree of partial melt. In the AFM diagram, these mafic rocks show iron enrichment trend which is a feature characteristics of tholeiitic magma and their Mg-tholeiitic nature is suggested by the Al-Fe+TiMg plot (Jensen 1976) (Fig. 5b). The high field strength elements plot of Ti/Y-Zr/Y (Fig. 5c) (Pearce and Gale 1977) reveals signature of the 'within plate' of these rocks and probably indicate generation of these intrusives in a continental rift/lithospheric extension tectonic environment (Thompson et al. 1983; Ahmad and Tarney 1994). Since a correlation of $\mathrm{Nb} / \mathrm{Th}$ with $\mathrm{Nb} / \mathrm{Yb}$ would be expected in the case of mixing between MORB and OIB source mantle (Munker 2000). The $\mathrm{Nb} / \mathrm{Th}$ ratios of these rocks do not correlate with $\mathrm{Nb} / \mathrm{Yb}$ ratios indicating significant role of OIB in the source can be ruled out.

These gabbros show REE patterns with enriched LREE and the slightly depleted HREE pattern with significant positive Eu anomalies $\left(\mathrm{Eu} / \mathrm{Eu}^{*}=1.00-1.30\right)$ (Fig. 6a). The significant positive Eu anomalies may be due to melting of plagioclase bearing source or accumulation of plagioclase during fractionalization of parental liquid. Their REE patterns are moderately steep $(\mathrm{Ce} / \mathrm{Yb})_{\mathrm{N}}(2.47-3.33)$ and sub-parallel to one another, indicating fractionation of REE in relatively constant proportions over a significant range of composition. The enrichment in LREE can be produced by melting of an enriched LREE mantle source, by crystal fractionation or by assimilation of continental crust (Moraes et al. 2003). The close bunching of the REE curves and trace elements patterns of the samples suggests that they belong to a chemically coherent group. These mafic rocks have smooth REE and coherent multi-elemental patterns of HFSEs indicating the incompatible trace elements and REEs are less affected and may reflect primary chemical characteristics of these rocks. Their primitive mantle normalized of these rocks shows gentle slope from left to right indicating their enrichment in the incompatible elements (Fig. 6b). These patterns display insignificance negative $\mathrm{Nb}, \mathrm{P}, \mathrm{Ti}$ anomalies with comparable 
Table 2: Major elements data and petrogenetic parameters of gabbro intrusive from the Panging area in Siang Window, the Arunachal Lesser Himalaya

\begin{tabular}{|c|c|c|c|c|c|c|c|c|}
\hline Sample No. & 3P1 & $3 \mathbf{P 3}$ & $4 \times 2$ & $4 \times 3$ & $4 \times 5$ & BR12 & BR47 & BR48 \\
\hline \multicolumn{9}{|c|}{ Major elements } \\
\hline $\mathrm{SiO}_{2}$ & 53.42 & 53.1 & 53.76 & 53.46 & 52.64 & 51.07 & 52.7 & 51.35 \\
\hline $\mathrm{TiO}_{2}$ & 1.59 & 1.64 & 1.58 & 1.62 & 1.63 & 2.28 & 1.25 & 1.68 \\
\hline $\mathbf{A l}_{2} \mathbf{O}_{3}$ & 14.78 & 14.65 & 14.07 & 14.3 & 15.09 & 13.06 & 14.73 & 14.41 \\
\hline $\mathrm{FeO}$ & 9.14 & 8.98 & 8.54 & 9.2 & 9.34 & 10.13 & 8.58 & 9.72 \\
\hline $\mathrm{Fe}_{2} \mathrm{O}_{3}$ & 1.79 & 1.76 & 1.67 & 1.8 & 1.83 & 1.99 & 1.68 & 1.91 \\
\hline MgO & 5.71 & 6.09 & 6.96 & 7.12 & 6.43 & 9.46 & 8.72 & 7.5 \\
\hline $\mathrm{CaO}$ & 6.37 & 6.48 & 7.48 & 6.63 & 9.55 & 7.93 & 7.13 & 9.5 \\
\hline $\mathrm{Na}_{2} \mathrm{O}$ & 3.6 & 3.84 & 3.59 & 3.85 & 3.32 & 2.33 & 2.38 & 3.15 \\
\hline $\mathbf{K}_{2} \mathbf{O}$ & 0.94 & 0.69 & 0.74 & 1.04 & 0.49 & 0.62 & 1.08 & 0.41 \\
\hline MnO & 0.14 & 0.13 & 0.13 & 0.14 & 0.14 & 0.15 & 0.13 & 0.15 \\
\hline $\mathbf{P}_{2} \mathbf{O}_{5}$ & 0.13 & 0.12 & 0.18 & 0.18 & 0.22 & 0.29 & 0.15 & 0.2 \\
\hline LOI & 1.56 & 1.74 & 1.19 & 1.44 & 0.94 & 1 & 1.51 & 0.54 \\
\hline Total & 99 & 99.04 & 99.72 & 100.02 & 101.44 & 100.11 & 99.87 & 100.32 \\
\hline $\mathrm{Na}_{2} \mathrm{O}+\mathrm{K}_{2} \mathrm{O}$ & 4.54 & 4.53 & 4.34 & 4.9 & 3.81 & 2.95 & 3.46 & 3.56 \\
\hline $\mathrm{Na}_{2} \mathrm{O} / \mathrm{K}_{2} \mathrm{O}$ & 3.82 & 5.53 & 4.82 & 3.69 & 6.78 & 3.76 & 2.2 & 7.68 \\
\hline $\mathrm{Fe}_{2} \mathrm{O} / \mathrm{MgO}$ & 1.88 & 1.74 & 1.44 & 1.52 & 1.71 & 1.26 & 1.16 & 1.52 \\
\hline $\mathrm{CaO} / \mathrm{TiO}_{2}$ & 4.02 & 3.96 & 4.75 & 4.08 & 5.86 & 3.48 & 5.7 & 5.65 \\
\hline $\mathrm{Al}_{2} \mathrm{O} / \mathrm{TiO}_{2}$ & 9.32 & 8.96 & 8.93 & 8.81 & 9.26 & 5.73 & 11.78 & 8.58 \\
\hline \multicolumn{9}{|l|}{ Agpaiitic } \\
\hline Index & 40 & 39.65 & 41.03 & 45.22 & 34.97 & 49.56 & 50.75 & 38.47 \\
\hline $\mathrm{CaO} \backslash \mathrm{Al}_{2} \mathrm{O}_{3}$ & 0.43 & 0.44 & 0.53 & 0.46 & 0.63 & 0.61 & 0.48 & 0.66 \\
\hline $\mathrm{Fe}_{2} \mathrm{O}_{3} \mid \mathrm{TiO}_{2}$ & 6.78 & 6.46 & 6.38 & 6.67 & 6.74 & 5.23 & 8.07 & 6.8 \\
\hline \multicolumn{9}{|c|}{ Petrogenetic parameters } \\
\hline Mg \# & 52.68 & 54.71 & 59.21 & 57.94 & 55.08 & 62.46 & 64.43 & 57.9 \\
\hline [Mg]\% & 16.63 & 17.45 & 18.61 & 19.41 & 16.21 & 20.04 & 20.16 & 17.35 \\
\hline$[\mathrm{Fe}] \%$ & 13.92 & 13.42 & 12.06 & 13.27 & 12.21 & 13.19 & 12.25 & 13.07 \\
\hline $\mathbf{K d}_{\mathrm{Mg}}$ & 5.87 & 5.66 & 5.25 & 5.1 & 5.51 & 3.9 & 4.3 & 4.77 \\
\hline$K d_{\mathrm{Fe}}$ & 2.38 & 2.27 & 2.11 & 2.01 & 2.24 & 1.59 & 1.77 & 1.92 \\
\hline KDX & 0.4 & 0.4 & 0.4 & 0.39 & 0.41 & 0.41 & 0.41 & 0.4 \\
\hline Fo-ol & 72.21 & 74.07 & 77.37 & 76.79 & 74.02 & 77.61 & 78.9 & 74.38 \\
\hline $\mathbf{T}^{0}$ liqC & 1,333 & 1,344 & 1,355 & 1,380 & 1,309 & 1,391 & 1,386 & 1,339 \\
\hline
\end{tabular}

$[\mathrm{Mg}]$ and $[\mathrm{Fe}]=$ compositionally corrected $\mathrm{Mg}$ and $\mathrm{Fe}$ abundances in cation mole percent using Ford et al. (1983) equation-3 based on compositionally corrected olivinemelt $k d s^{\prime}$ for $\mathrm{MgO}$ and $\mathrm{FeO} ; \mathrm{Kd}_{\mathrm{Mg}}=$ concentration of $\mathrm{Mg}$ in olivine/concentration of $\mathrm{Mg}$ in liquid; $K d_{\mathrm{Fe}}=$ concentration of Fe olivine / concentration of $\mathrm{Fe}$ in liquid; $K D X$ $=K d_{F e} / K d_{M g} ; F o-o l=$ forsterite content of olivine with which liquid in equilibrium; $T^{o}$ liqC = one atmosphere $(0.001 \mathrm{~kb})$ liquid olivine temperature calculated using equation -3 of Ford et al. (1983). A, B and $C$ are calculated solidii for $25 k$ bar and 1 atm. pressure respectively

concentrations of large ion lithophile elements (such as $\mathrm{K}$, $\mathrm{Rb}, \mathrm{Th}, \mathrm{Ba}$ and $\mathrm{Sr}$ ). Crustal materials are rich in LILE, $\mathrm{K}_{2} \mathrm{O}$ and $\mathrm{Na}_{2} \mathrm{O}$ and depleted in $\mathrm{P}_{2} \mathrm{O}_{5}$ and $\mathrm{TiO}_{2}$, hence, crustal contamination will increase $\mathrm{K}_{2} \mathrm{O}, \mathrm{Na}_{2} \mathrm{O}$ and LILE, and decrease $\mathrm{P}_{2} \mathrm{O}_{5}$ and $\mathrm{TiO}_{2}$. Lightfoot et al. (1993) suggested the primitive mantle normalized patterns with negative $\mathrm{Nb}, \mathrm{P}, \mathrm{Ti}$ anomalies and variable anomalies in $\mathrm{Rb}, \mathrm{K}, \mathrm{Ba}, \mathrm{Sr}$ indicating crustal contamination in the rocks. Low concentrations and narrow ranges of LILE with $\mathrm{K}_{2} \mathrm{O}$ and $\mathrm{Na}_{2} \mathrm{O}$, high contents of $\mathrm{Fe}_{2} \mathrm{O}_{3}$ with insignificance negative $\mathrm{Nb}, \mathrm{P}, \mathrm{Ti}$ anomalies in the gabbros suggest that these rocks have not undergone considerable crustal contaminations (Arndt and Jenner 1986; Lightfoot et al. 1993; Ahmad et al. 1999). These mafic rocks also do not show any subduction zone signature and they have lower and higher trace elements concentrations as compared with those of OIB and N-MORB respectively.

Petrogenetic parameters for these mafic rocks are calculated based on the $[\mathrm{Mg}]-[\mathrm{Fe}]$ modeling (Hanson and Langmuir 1978; Langmuir and Hanson 1980; Rajamani et al. 
Geochemical and biostratigraphic constraints on the genesis of mafic intrusive

Table 3: Trace and rare earth elements data of gabbro intrusive of Panging area in Siang Window of the Arunachal Lesser Himalaya

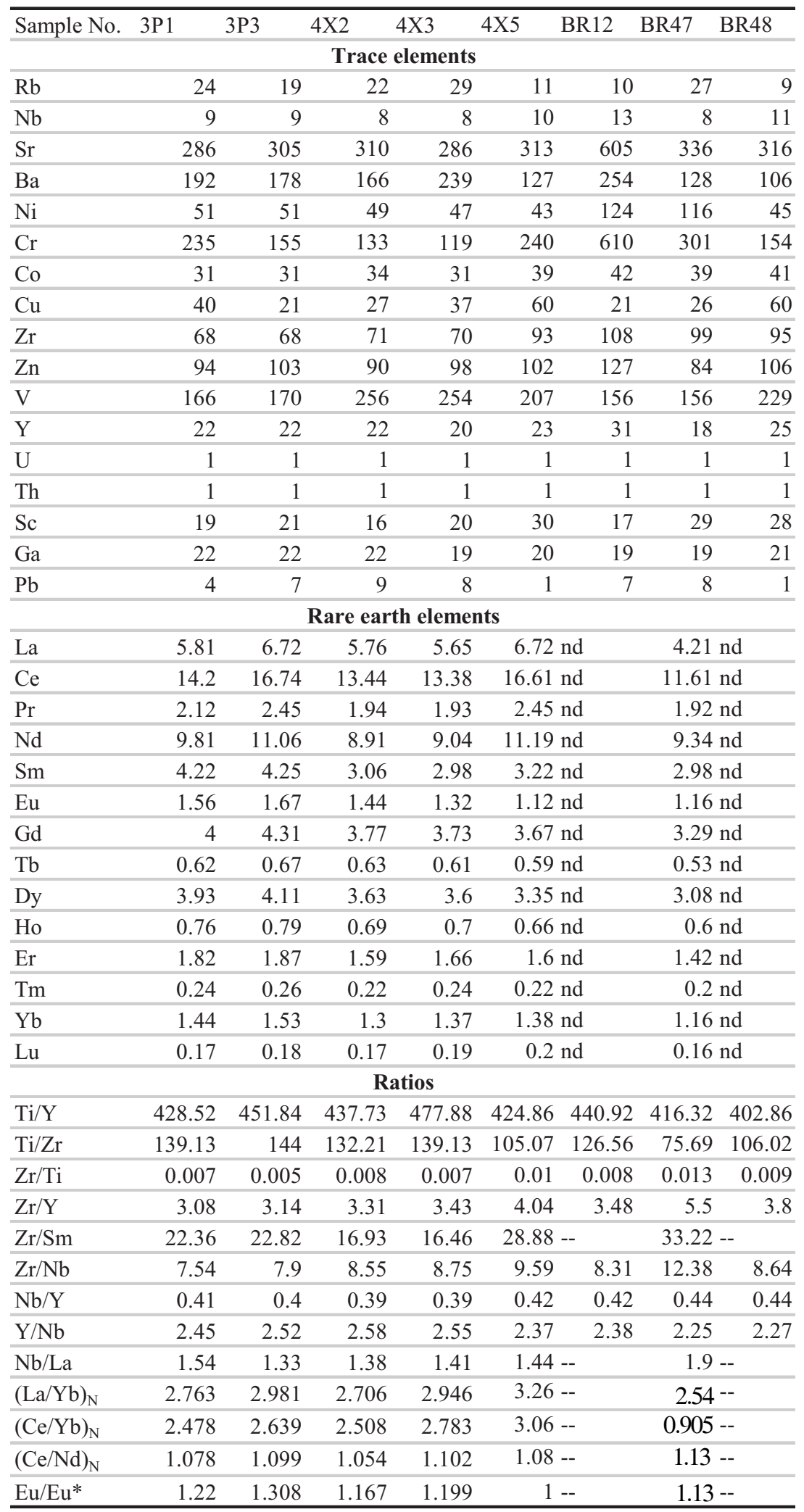

$n d=$ not determined 

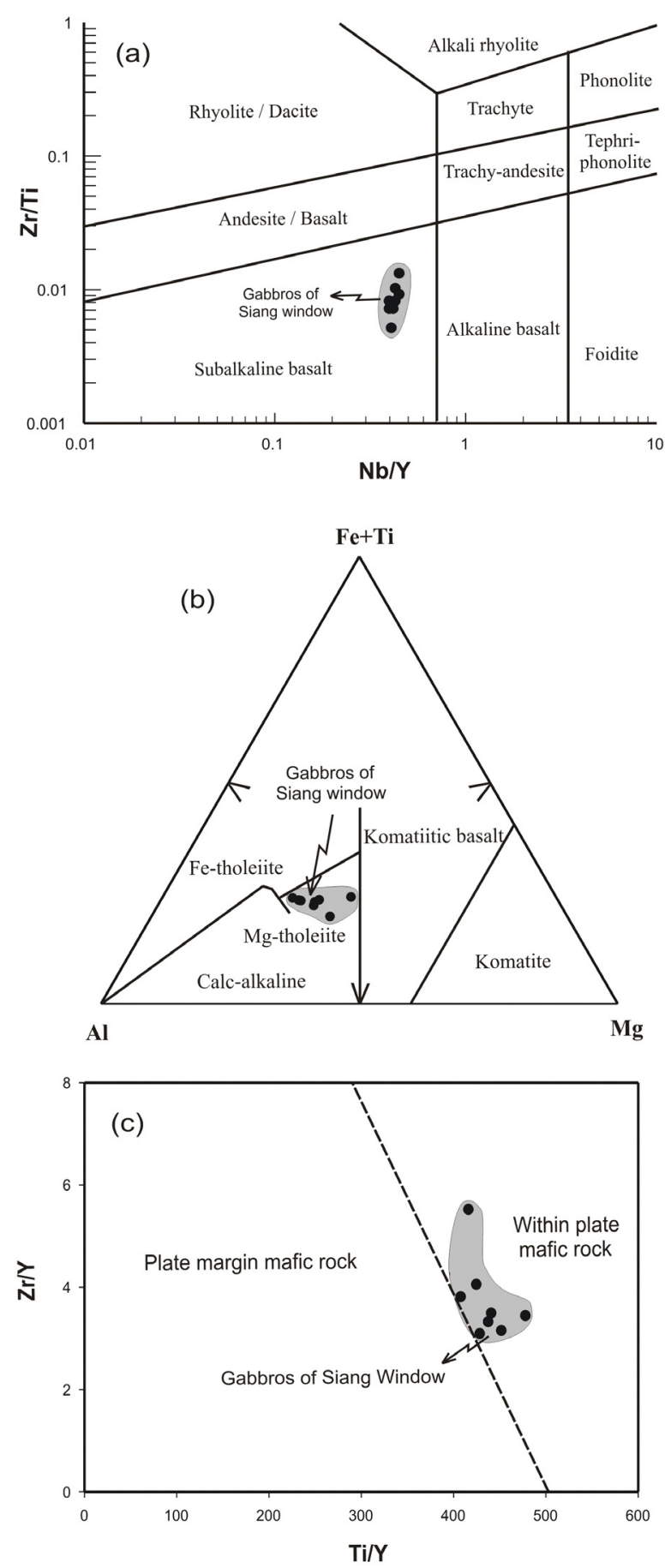

Fig. 5: (a) $\mathrm{Nb} / \mathrm{Y}$ vs $\mathrm{Zr} / \mathrm{Ti}$ diagram (after Pearce 1996). (b) Cation percent Al-(Fe+Ti) - Mg plot (after Jensen 1976). (c) $\mathrm{Ti} / \mathrm{Y}$ vs $\mathrm{Zr} / \mathrm{Y}$ plot for gabbro intrusive of Panging area, the Arunachal Lesser Himalaya

1993). The [Mg]-[Fe] values plot in the calculated melt fields on the $[\mathrm{Mg}]-[\mathrm{Fe}]$ diagram (Fig.7a) for theoretical melting of garnet-lherzolite with $\mathrm{MgO}=37.9$ and $\mathrm{FeO}=10.2$ at 0,3 ( $100 \mathrm{~km}$ depth) and 5 Ga pressure (Rajamani et al. 1993). The solidii for 0,3 and $5 \mathrm{GPa}$ pressures are based on the
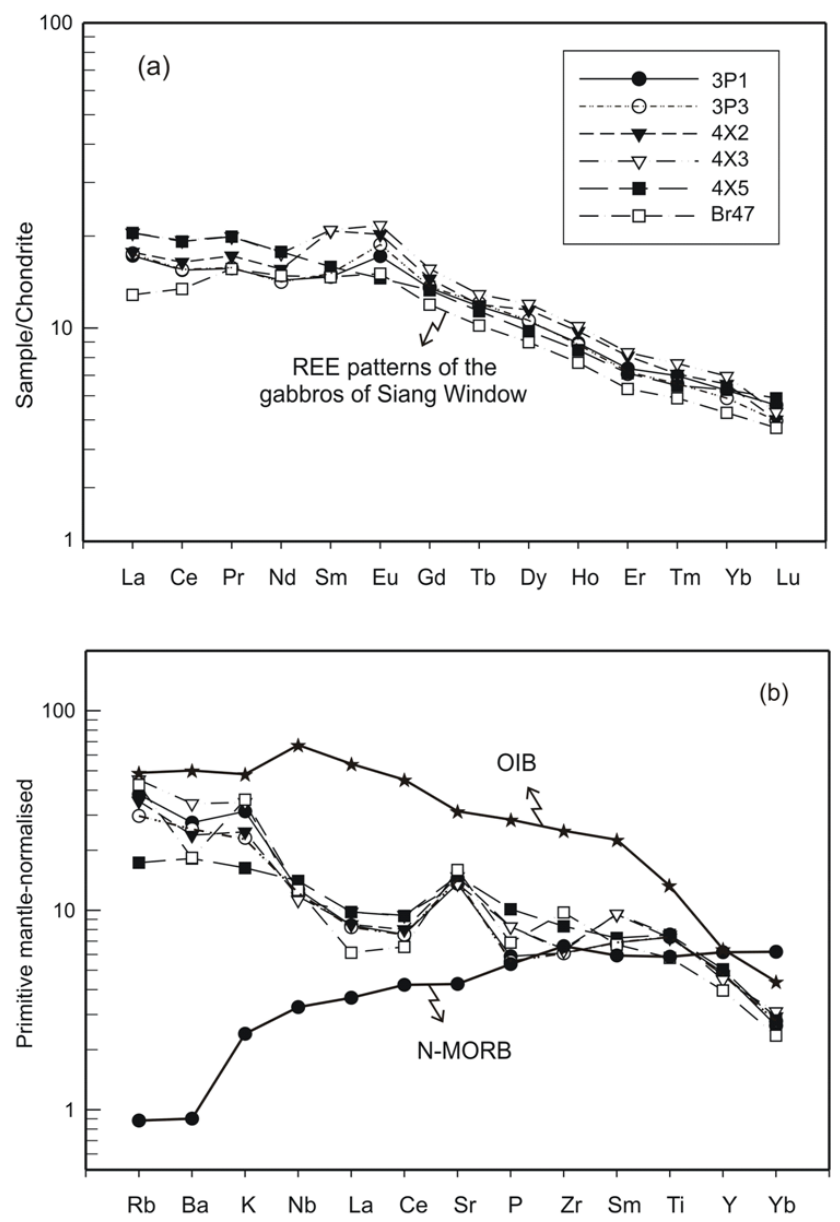

Fig. 6: (a) Chondrite-normalized REE plots (normalizing factors are from Nakamura 1974). (b) Primitive mantle normalized elements patterns (normalizing factors are from Sun and McDonough 1989) for gabbro intrusive of Panging area, the Arunachal Lesser Himalaya

experimental work of Takahashi (1986). These mafic rocks are cluster outside the melt field, suggesting that they are not genetically related with the garnet-lherzolite source. Even if we assume that they had undergone $20 \%$ olivine fractional crystallization, their parental magma would still plot outside the melt field. Hence, the source rock of this gabbroic magma had a much higher Fe/Mg ratio relative to garnet-lherzolite/ pyrolite source (Rajamani et al. 1989; Ahmad and Tarney 1991).

The lithospheric sources have a higher $\mathrm{Fe} / \mathrm{Mg}$ ratio than that of pyrolite or lherzolite as a result of addition of melts generated at deeper levels (Ahmad and Rajamani 1991). The Komatiitic amphibolites reported from Kolar Schist Belt have higher Fe/Mg ratio than garnet-lherzolite (Rajamani et al. 1985). Calculated [Mg]-[Fe] melt fields for a Komatiitic source having 29.21 mole $\% \mathrm{MgO}$ and 8.47 mole $\% \mathrm{FeO}$ for 1 atmosphere and $25 \mathrm{~kb}$ pressures are shown in Fig. 7a. The primitive samples $(4 \mathrm{X} 2,4 \mathrm{X} 3, \mathrm{BR} 12, \mathrm{BR} 47)$ plot inside the 

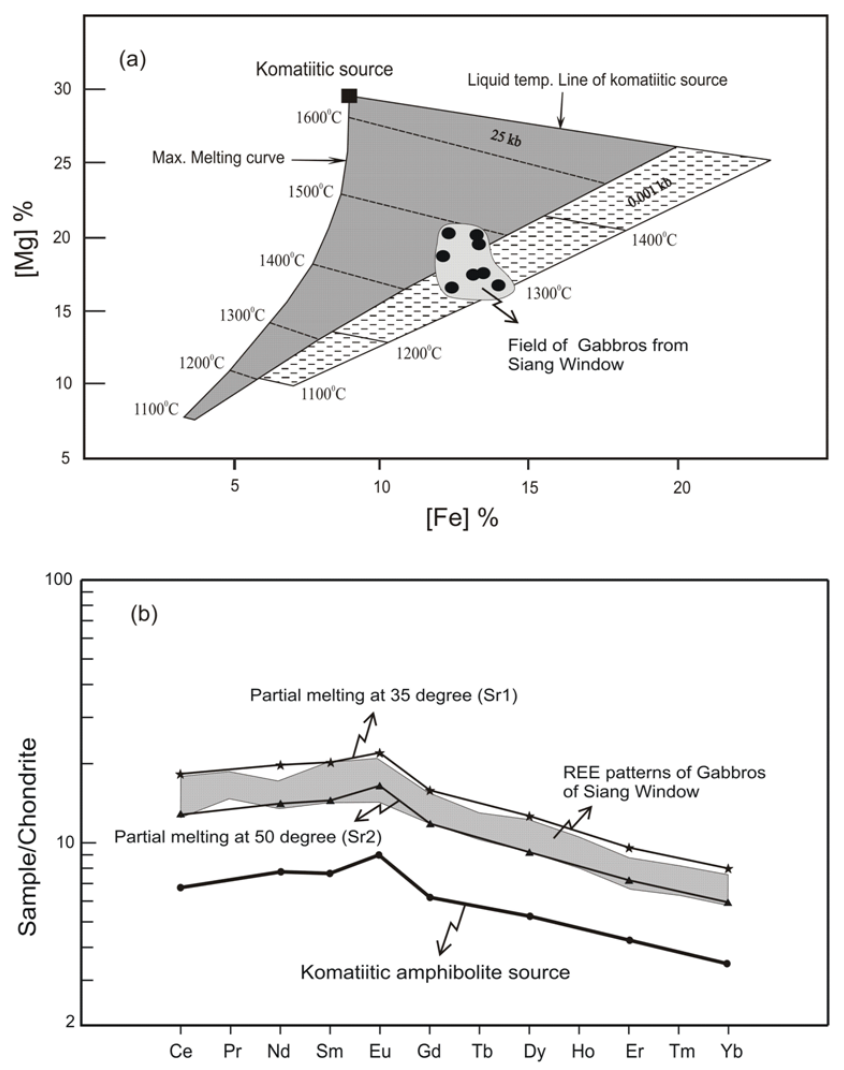

Fig. 7: (a) Calculated [Fe]-[Mg] plot for gabbro intrusive of Panging area, Eastern Himalaya are plotted in the melt field of Komatitic source at $1 \mathrm{~atm}$. and $25 \mathrm{~kb}$ (after Rajamani et al. 1985). (b) Chondrite-normalized REE plot showing the zone for the mafic intrusive of Panging area and their calculated source. The $\mathrm{Sr} 1$ and $\mathrm{Sr} 2$ represent REE patterns of this model source were calculated using Batch melting equation (Schilling 1966) based on Kd values (McKenzie and O'Nions 1991) assuming a Komatitic mantle source (37\% ol; $51 \%$ opx; $12 \%$ cpx) leaving a residue with $35 \%$ ol; 50\% opx; $15 \%$ cpx at $35 \%$ and $50 \%$ partial melting respectively.

melt field suggesting that they represent primary melt composition having high $\mathrm{Mg}$ (57.94 - 64.43) and liquidus olivine temperature $\left(1355^{\circ} \mathrm{C}-1386^{\circ} \mathrm{C}\right)$. The linear trend of incompatible elements like $\mathrm{Zr}, \mathrm{Nb}$ and $\mathrm{P}$ in the primitive mantle normalized suggests that they may be cogenetic in nature (Keppler 1996). Values of highly incompatible trace elements such as $\mathrm{Nb} / \mathrm{La}$ and $\mathrm{Ce} / \mathrm{Nd}$ normally change very little with moderate degrees of fractional crystallization and are expected to reflect the source characteristics (Saunders et al. 1988). However, these ratios may be fractionated to some extent by extremely low degrees of partial melting (McKenzie 1989) or due to compositional heterogeneities, in the source region (Ahmad and Tarney 1994). Thus, the narrow variation of $\mathrm{Nb} / \mathrm{La}(1.33-1.90)$ and $(\mathrm{Ce} / \mathrm{Nd})_{\mathrm{N}}(1.05-$ 1.38) ratios in these rocks suggest that they are derived from similar sources. Enrichment of incompatible trace elements in the source of these rocks is indicated by the $\mathrm{Zr}-\mathrm{Y}$ relationship.

A primitive mantle is considered as source rock that consists of 49.9 wt. $\% \mathrm{SiO}_{2}, 35$ wt. $\% \mathrm{MgO}, 8$ wt. \% FeO, 2000 ppm Ni and $8.3 \mathrm{ppm} \mathrm{Zr}$ (Taylor and McLennan 1985). REE patterns for $5 \%$ and $10 \%$ melting of the primitive mantle source has been calculated using Batch melting equation: $\mathrm{C}_{\mathrm{L}} / \mathrm{C}_{\mathrm{O}}=1 / \mathrm{D}(1-\mathrm{F})+\mathrm{F}$ (Schilling 1966) based on Kd values of McKenzie and O'Nions (1991) where $C_{L}=$ concentration of element in the melt, $\mathrm{C}_{\mathrm{O}}=$ concentration of element in the original source, $\mathrm{D}=$ bulk distribution coefficient and $\mathrm{F}=$ degree (5) of partial melt. Melt generated by 5\% partial melting of the primitive mantle source leaving $40 \%$ olivine, $34 \%$ opx, $15 \%$ cpx and $11 \%$ plagioclase in the residue whereas $10 \%$ partial melting of the same source leaving a residue comprised $33 \%$ olivine, $45 \%$ opx and $19 \% \mathrm{cpx}$ has been calculated. The calculated melt at $5 \%$ and $10 \%$ are plotted much lower than the REE patterns of these mafic rocks. Hence, different degrees of partial melting of the primitive mantle can not explain the various elemental abundances in these mafic rock samples. It also suggests that the source of the mafic rocks has lower $\mathrm{Ni}$ and higher $\mathrm{Zr}$ and REEs than the primitive mantle source.

To evaluate the source rock of the present investigated mafic intrusive rocks, a komatiitic amphibolite sample (no. SB 27-2) from Kolar Schist Belt (Balakrishnan 1986) has been considering as the source. This source has $47.80 \% \mathrm{SiO}_{2}$, $11.02 \% \mathrm{FeO}, 24.47 \% \mathrm{MgO}, 1490 \mathrm{ppm} \mathrm{Ni}$ and $36 \mathrm{ppm} \mathrm{Zr}$ and the normative mineralogy is $33 \%$ olivine and $67 \%$ pyroxene. It shows LREE enriched chondrite normalized with marked the positive Eu anomaly REE pattern. Fig. 7b shows chondrite normalized REE patterns for partial melts derived from the source and zone for the REE concentrations of gabbroic intrusive. $\mathrm{Sr}_{1}$ and $\mathrm{Sr}_{2}$ represent REE patterns of source derived by $32 \%$ and $47 \%$ partial melting leaving a similar residue with $35 \%$ olivine; $50 \%$ opx; $15 \%$ cpx. The calculated melt $\left(\mathrm{Sr}_{1}\right)$ at 35\% partial melting closely approaches the higher REE abundances whereas the calculated melt $\left(\mathrm{Sr}_{2}\right)$ at $50 \%$ partial melting closely approaches the lower REE abundances of the gabbros of Panging area. The similarity of REE patterns of the gabbro intrusive to the calculated REE patterns suggest that the REE abundances of these gabbros are possibly derived from the komatiitic amphibolite source. Hence, this gabbro intrusive could have been derived by different degrees of partial melting of source rock similar of komatiitic amphibolites / picritic composition.

\section{MICROFOSSILS, DEPOSITIONAL ENVIRONMENT AND AGE OF THE BUXA - MIRI SEDIMENTS OF THE ARUNACHAL LESSER HIMALAYA}

Radiating filaments of Rivularia haematites (Cyanophyta) has been recorded for the first time from the Panging Limestone (Fig. 4a). It is also found to be associated with semi coiled filament showing septae (Fig. 4b). Both microfossils are cyanobacterial remains of Neoproterozoic 
age. The genus Rivularia belongs to the family Rivulariaceae, a non motile filamentous cyanobacterial form. The radiating filaments are found in the microenvironments favourable for autochthonous calcite precipitation. The marine species of the Rivularia generally do not form Stromatolites; therefore, no Stromatolitic structures have been recorded from the Panging Limestone. A shallow marine depositional environment is suggested for the Panging Limestone. The present microfossils are indicative of an intertidal to supratidal zone which is also suggested by the fenestral vuggy and zebra fabric found in the Panging Limestone (Fig. 2). Neoproterozoic to Lower Cambrian age has been suggested to the Buxa-Miri Group sediments of the Arunachal Lesser Himalaya from Kameng, Subansiri and West Siang districts on the basis of organic walled microfossils, stromatolites, microstromatolites, sponge spicules, sponges and ichnofossils (Tewari 1998, 2001, 2002, 2003, 2007, 2009, Shukla et al. 2006). The carbon and oxygen isotopic profiles obtained for the Buxa (Menga, Chillipam and Dedza) Dolomites (Tewari 2002,2003 , 2007) also suggest that these isotopic values are comparable with other Neoproterozoic (Ediacaran/Vendian) carbonates of the western Lesser Himalaya and their equivalents in other parts of the world.

\section{CONCLUSIONS}

Geochemically the gabbro intrusive in Panging area is Mg-tholeiitic in nature (enriched in LILE and LREE; depleted in HFSE; minor REE fractionated nature) and classified as low-Ti (Ti/Y = 416.32 - 477.88; Nb/La = 1.33 - 1.90) mafic rocks. Similarity, in immobile trace element and REE abundances reveal their cogenetic nature. These mafic intrusive rocks do not show any subduction zone signature in their chemistry and their trace elements concentrations are much lower and higher as compared with those of OIB and N-MORB respectively. It is also suggested that these intrusive rocks have the influence of a within plate signature which were intruded in a continental rift/ lithospheric extension tectonic environment. The $[\mathrm{Mg}]-[\mathrm{Fe}]$ and REE petrogenetic modellings indicate that these rocks derived from enriched mantle source with higher Fe/Mg ratio than primitive mantle source. The comparable REE patterns for these intrusive rocks and calculated parent melt suggest that these mafic rocks might have derived from a source similar to komatiitic composition at moderate to higher degree of partial melt. The age of the Buxa-Miri Group as already discussed that range from Neoproterozic to Lower Cambrrian. The present record of the microfossil Rivularia haematites and other coiled cyanobacterial remains indicate Neoproterozoic age for the Buxa (Panging Limestone). Therefore, based on the present reported microfossils, it is concluded that gabbroic intrusion in the Panging Limestone is probably post Neoproterozoic and pre Lower Cambrian in age which is probably close to the Precambrian-Cambrian boundary.

\section{ACKNOWLEDGEMENTS}

The authors are thankful to Prof. A. K. Gupta, Director and Dr. A. K. Dubey, former Acting Director, WIHG for permission to published the paper and providing necessary facilities. Thanks are due to Dr. P. P. Khanna and Dr. N. K. Saini, WIHG for the geochemical analyses. Modifications and corrections suggested by two anonymous reviewers are gratefully acknowledged.

\section{REFERENCES}

Acharyya, S. K., 2007, Evolution of the Himalayan Paleogene foreland basin, influence of its litho-packet Eastern HimalayasA review. Jour. Asian Earth Sci., v. 31, pp.1-17.

Acharyya, S. K., 1998, Thrust tectonics and evolution of domes and the syntaxis in Eastern Himalaya, India. Jour. Geol. Soc. Nepal, v. 18, pp.1-17.

Acharyya, S. K., Mitra, N. D., and Nandy, D. R., 1986, Regional geology and tectonic setting of Northeast India and adjoining region. Geol. Suv. India, Memoirs, v. 119, pp. 6-12.

Ahmad, T. and Bhatt, I. M., 1987, Geochemistry and petrogenesis of the Mandi-Darla volcanics, northwestern Himalayas. Precam. Res., v. 37, pp. 231-256.

Ahmad, T. and Rajamani, V., 1991, Geochemistry and petrogenesis of the basal Aravalli volcanics near Nathdwara, Rajasthan, India. Precam. Research, v. 49, pp. 185-204.

Ahmad, T. and Tarney, J., 1991, Geochemistry and petrogenesis of Garhwal volcanics: implications for evolution of the north India lithosphere. Precam. Res., v. 50, pp. 69-88.

Ahmad, T. and Tarney, J., 1994, Geochemistry and petrogenesis of late Archaean Aravalli volcanics, basement enclaves and granitoids, Rajasthan. Precam. Res., v. 65, pp.1-23.

Ahmad, T., Mukherjee, P. K., and Trivedi, J. R., 1999, Geochemistry of Precambrian mafic magmatic rocks of the western Himalaya, India: petrogenetic and tectonic implications. Chemical Geology, v. 160, pp. 103-119.

Arndt, N. T. and Jenner, G. A., 1986, Crustally contaminated komatites and basalts from Kambalda, Western Australia. Chem. Geol., v. 56, pp. 229-255.

Balakrishnan, S., 1986, Geochemical and isotopic studies of the Komatiitic rocks of Kolar Schist Belt, South India, Unpub. Ph.D. Thesis, Jawaharlal Nehru University, New Delhi.

Bhat, M. I., 1984, Abor volcanics: further evidence for the birth of the Tethys Ocean in the Himalyan segment. Jour. Geol. Soc. London, v. 141, pp. 763-775.

Bhat, M. I. and Le Fort, P., 1992, Nd-isotopic study of the late Archaean continental tholeiites, NW Lesser Himalayas: a case of ocean island basalt source for continental tholeiites. Jour. Him. Geol, v. 4(1), pp.1-13.

Bhat. M. I. and Ahmad, T., 1990, Petrogenesis and the mantle source characteristic of the Abor volcanic rocks, Eastern Himalayans. Jour. Geol. Soc. India, v. 36, pp. 227-246.

Burg, J. P., Nievergelt, P., Oberli, F., Seward, D., Davy, P., Maurin, J. C., Diao, Z. Z., and Meier, M., 1998, The Namche Barwa syntaxis: Evidence for exhumation related to compressional crustal folding. Jour. Asian Earth Sci., v. 16, pp. 239-252.

Chaudhari, N. and Gupta, L. N., 1997, Petrogenesis of the Mandi Gabbroic rocks, Lesser Himalaya, India. Jour. Geol. Soc. India, v. 50, pp. 49-59. 
Ding, L., Zhong, D. L., Yin, A., Kapp, P., and Harrison, T. M., 2001, Cenozoic structural and metamorphic evolution of the eastern Himalayan syntaxis (Namche Barwa), Earth Plan. Sci. Lett., v. 192, pp. 423- 438.

Ford, C. E., Russel, D. G., and Frisk, M. R., 1983, Olivine-liquid equilibria: temperature, pressure and composition dependence of the crystal/liquid partition coefficients for $\mathrm{Mg}, \mathrm{Fe}^{2+}, \mathrm{Ca}$ and Mn. Jour. Petrology, v. 24, pp. 256-265.

Gautam, P., Upreti, B. N. and Arita, K., 1995, Paleomagnetism and petrochemistry of the Dowar Khola volcanics, Central Nepal Sub Himalaya. Jour. Geol. Soc. Nepal, v. 11, pp. 179-195.

Gururajan, N. S. and Choudhuri, B. K., 2003, Geology and tectonic history of the Lohit Valley, Eastern Arunachal Pradesh, India. Jour. Asian Earth Sci., v. 21, pp. 731-741.

Hanson, G. N. and Langmuir, C. H., 1978, Modeling of major element in mantle melt system using trace element approaches. Geochim. Cosmochim. Acta. v. 42, pp. 725-741.

Jensen, L. S., 1976, A new cation plot for classifying sub-alkaline volcanic rocks. Misc. Paper, Ontario, Div. Mines No. 66.

Keppler, H., 1996, Constraints from partitioning experiments on the composition of subduction-zone fluids. Nature, v. 380, pp. 237-40.

Kumar, G., 1997, Geology of Arunachal Pradesh, Geological Society of India, Bangalore, 217 p.

Lafleche, M. R., Dupuy, C., and Bougault, H., 1992, Geochemistry and petrogenesis of Archean mafic volcanic rocks of the southern abitibi Belt, Quebec. Precam. Res., v. 57, pp. 207-241.

Langmuir, C. H. and Hanson, G. N., 1980, An evaluation of major element heterogeneity in the mantle sources of basalts. Philos. Trans. Royal Soc. London, v. A297, pp. 383-407.

Lightfoot, P. C., Hawkesworth, C. J., Hergt, J., Naldrett, A. J., Gorbachev, N. S., Fedorenko, V. A., and Doherty, W., 1993, Remobilisation of the continental lithosphere by a mantle plume: major-trace elements and $\mathrm{Sr}-\mathrm{Nd}$ and $\mathrm{Pb}$ - isotope evidence from picritic and tholeiitic lavas of the Noril'sk District, Siberian Trap, Russia. Cont. Min. Petrol., v. 144, pp. 171-188.

Liu, Y., Berner, Z., Massonne, H. J. and Xiao, X., 2004, Geology of the Eastern Himalyan Syntaxis. $19^{\text {th }}$ HKT Workshop, Niseko, Japan, Abstract, Him. Jour. Sci. v. 2, pp.197-198.

Mahoney, J. J., Sheth, H. C., Chandrasekharam, D., and Peng, Z. X., 2000, Geochemistry of flood basalts of the Toranmal section, northern Deccan Traps, India: implications for regional Deccan stratigraphy. Jour. Petrol., v. 41, pp.1099-1120.

Mckenzie, D., 1989, Some remarks on the movement of small melt fractions in the mantle. Earth and Plan. Sci. Lett., v. 95, pp. 53-72.

McKenzie, D. P. and O’Nions, R. K., 1991, Partial melt distributions from inversion of rare earth element concentrations. Jour. Petrol. v. 32, pp. 1021-1091.

Moraes, R., Fuck, R. A., Pimentel, M. M., Gioia, S. M .C. L. and Figueiredo, A. N. G., 2003, Geochemistry and Sm-Nd isotopic characteristics of bimodal volcanic rocks of Juscelandia, Goias, Brazil: Mesoproterozoic transition from continental rift to Ocean basin. Precam. Res., v. 125, pp. 317-336.

Munker, C., 2000, The isotope and trace element budget of the Cambrian Devil River Arc System, New Zealand: identification of four source components. Jour. Petrol., v. 41, pp. 759-88.

Nakamura, 1974, Determination of REE, Ba, Fe, Mg, Na and K in carbonaceous and ordinary chondrites. Geochemica et Cosmochemica Acta, v. 38, pp. 757-775.
Pearce, J. A. 1996, A user's guide to basalt discrimination diagrams. In: Trace element geochemistry of volcanic rocks; applications for massive sulphide exploration., Geological Association, Canada, (Geol. Asso. Can.), v. 12, pp. 79-113.

Pearce, J. A. and Gale, D. H., 1977, Identification of ore deposition environment from trace element geochemistry. Geol. Soc. London, Spec. Publ., v. 7, pp. 14-24.

Peate, D.W., Hawkesworth, C. J. and Mantovani, M. S. M., 1992, Chemical stratigraphy of the Parana lavas (South America): Classification of magma-types and their spatial distribution. Bulletin, Volcano, v. 55, pp. 119-139.

Rajamani, V., Balakrishnan, S., and Hanson, G. N., 1993, Komatite genesis: insights provided by $\mathrm{Mg}-\mathrm{Fe}$ exchange equilibria. Jour. Geol., v. 101, pp. 809-819.

Rajamani, V., Shirey, S. B., and Hanson, G. N., 1989, Fe-rich Archaean tholeiites derived from melt enriched mantle sources: evidence from the Kolar Schist Belt, South India. Jour. Geology, v. 97, pp. 487-501.

Rajamani. V., Shivkumar, K., Hanson, G. N., and Shirey, S. B., 1985, Geochemistry and petrogenesis of amphibolites, Kolar Schist Belt, South India: evidence for komatiitic magma derived by low percentages of melting of the mantle. Jour. Petrol. v. 26, pp. 92-123.

Roychowdhury, J., 1984, The Abor group of rocks in Arunachal Pradesh. Record of Geological Survey of India, v.113 (4), pp. 48-57.

Sage, R. P., Lightfoot, P. C., and Doherty, W., 1996, Bomodal cyclical Archean basalts and rhyolites from the Michipicoten (Wawa) greenstone belt, Ontario: geochemical evidence for magma contributions from the asthenospheric mantle and ancient continental lithosphere near the southern margin of the Superior Province. Precam. Res., v. 76, pp.119-153.

Saunders, A. D., Norry, M. J., and Tarney, J., 1988, Origin of MORB and chemically depleted mantle reservoirs: trace element constraints. In: Menzies, M. A. and Cox, K.G. (eds.), Oceanic and Continental: Similarities and differences. Jour. Petrol., pp. 415-455.

Schilling, J. G., 1966, Rare earth fractionation in Hawaiian volcanic rocks; Unpublished Ph.D. Thesis. Mass. Inst. Tech., (USA: Cambridge MA).

Sengupta, S., Acharyya, S. K. and De Smeth, J. B., 1996, Geochemical characteristics of the Abor volcanics, NE Himalaya, India: nature and early Eocene magmatism. Jour. Geol. Soc. London, v. 153, pp. 695-704.

Shukla, M., Tewari, V. C., Babu, R., and Sharma, A., 2006, Microfossils from the Buxa Dolomite, West Siang district, Arunachal Lesser Himalaya, India and their significance. Paleont. Soc. India, v. 51 (1), pp. 57-73.

Singh, A. K., 2006, Petrography, Geochemistry and Petrogenesis of Abor Volcanics, Eastern Himalayan Syntaxial Bend. Him. Geology, v. 27 (2), pp.163-181.

Singh, S., 1993, Geology and Tectonics of the Eastern syntaxial Bend, Arunachal Himalaya. Jour. of Him. Geology, v. 4(2), pp.149-163.

Srivastava, R. K and Sahail, A., 2001, High-Field Strength Element Geochemistry of Mafic Intrusive Rocks from the Bhagirathi and Yamuna Valleys, Garhwal Himalaya, India. Gond. Res., v. 4 (3), pp. 455-463.

Sun, S. S. and McDonough, W. F.,1989, Chemical and isotopic systematics of oceanic basalts: implications for mantle composition and processes. In: Saunders A. D. \& Norry, M.J. 
(eds.), Magmatism in the Ocean basins. Jour. Geol. Soc., London, Spec. Publ., v. 42. pp. 313-145.

Takahashi, E., 1986, Melting of dry peridotite Kbr upto 14 Gpa: implications on the origin of peridotite upper mantle. Jour. Geophy. Res., v. 91, pp. 9367-9382.

Taylor, S. R. and McLennan, S. M., 1985, The continental crust: Its composition and evolution. Black Well scientific, Oxford, $312 \mathrm{p}$.

Tewari, V. C., 1998, Prospects of delineating Terminal Proterozoic and Precambrian - Cambrian boundary in the Northeastern Himalaya. Geoscience Journal, v. XIX (2), pp.109-113.

Tewari, V. C., 2001, Discovery and Sedimentology of microstromatolites from Menga Limestone ( Neoproterozoic / Vendian ), Upper Subansiri district, Arunachal Pradesh, North Eastern Himalaya, India. Current Science, v. 80 (2), pp. 1041-1044.

Tewari, V. C., 2002, Stratigraphy, Sedimentation and Correlation of the Lesser Himalaya from Uttaranchal to Arunachal. Gyanodaya Publishers, Nainital, pp. 63-88.

Tewari. V. C., 2003, Sedimentology, paleobiology and isotope chemostratigraphy of the Buxa Dolomite, Arunachal Pradesh, NE Lesser Himalaya. Jour. Him. Geol., v. 24 (2), pp.1-18.

Tewari, V. C., 2007, Rise and decline of Ediacaran biota: Paleobiological and stable isotopic evidence from the NW and
NE Lesser Himalaya, India. Geological Society of London, Spec. Publ, v. 296, pp. 77-101.

Tewari, V. C., 2009, Proterozoic unicellular and multicellular fossils from India and their implications. In: J. Seckbach (Ed.), From Fossils to Astrobiology. Springer, pp.119-139.

Thakur, V. C. and Jain, A. K., 1974, Tectonics of eastern region: India, Current Science, v. 43, pp. 783-785.

Thompson, R. N., Morrison, M. A., Dickin, A. P., and Hendry, G. L., 1983, Continental flood basalts-arachnids rule OK? In: C. J. Hawkesworth and M. J. Norry (eds.), Continental basalt and mantle xenoliths. Shiva Publ. Nantwich, pp. 158-185.

Wadia, D. N., 1931, The syntaxis of Northwest Himalaya: its rocks, tectonics and orogeny. Records Geol. Surv. India, v. 6, pp. $189-220$.

Winchester, J. A. and Floyd, P. A., 1977, Geochemical discrimination of different magma series and their differentiation products using immobile elements. Chem. Geol. v. 20, pp. 325-344.

Xu, Y., Chung, S. L., Jahn, B., and Wu, G., 2001, Petrologic and geochemical constraints on the petrogenesis of PermianTriassic Emeishan flood basalts in southwestern China, Lithos, v. 558, pp.145-168. 